\title{
Sağlık Hizmetleri Meslek Yüksekokulu Öğrencilerinde Dürtüsellik Düzeyleri ve Sosyal Medya Bağımlılığı Arasındaki İlişki
}

\section{Relationship Between Impulsivity Levels and Social Media Addiction in Health Services Vocational School Students}

\author{
Zehra Su Topbaş ${ }^{1}$ iD, Arzu Karakay ${ }^{2}$ (iD \\ 1. Erciyes Üniversitesi, Sağlık Bilimleri Fakültesi, Ruh Sağlığı ve Hastalıkları Hemşireliği Anabilim Dalı, Kayseri, \\ 2. Muş Alparslan Üniversitesi, Sağılık Hizmetleri Meslek Yüksekokulu, Engelli Bakımı ve Rehabilitasyon Anabilim Dalı, Muş
}

\section{Abstract}

Objective: The aim of this study is to examine the relationship between impulsivity levels of university students and social media addiction and the difference between impulsivity and social media addiction according to gender variable.

Method: The correlation design of the quantitative research method was used. The study was conducted with 306 students studying at a health services vocational school. Sociodemographic Data Collection Forum, Short Form of Barratt Impulsiveness Scale (BIS-11-SF) and Social Media Addiction Scale-Adult Form were used to collect data.

Results: As a result of statistical analysis, it was seen that there was a positive significant relationship between impulsivity level and social media addiction scores, and it was found that the impulsivity variable explained $18 \%$ of the total variance $(R=.18, p=.00)$. It was observed that there was no significant difference in the impulsivity level and social media addiction of women and men.

Conclusion: In this sample of Health Services Vocational School students, impulsivity predicts social media addiction.

Keywords: Social media, social networking, addiction, addictive behavior

Öz

Amaç: Bu çalışmanın amacı üniversite öğrencilerinin dürtüsellik düzeyleri ile sosyal medya bağımlılı̆ı arasındaki ilişkiyi ve cinsiyet değişkenine göre dürtüsellik ve sosyal medya bağımlıı̆ı arasındaki farkı incelemektir.

Yöntem: Nicel araştırma yönteminin korelasyon deseni kullanılmıştır. Çalışma bir sağlık hizmetleri meslek yüksekokulunda öğrenim gören 306 öğrenci ile yürütülmüştür. Veri toplamak için Sosyodemografik Veri Toplama Forumu, Barrat Dürtüsellik Ölçeği Kısa Formu ve Sosyal Medya Bağımlıı̆ı Ölçeği- Yetişkin Formu (SMBÖ-YF) kullanılmıştır.

Bulgular: Yapılan istatistiksel analizler sonucunda, dürtüsellik düzeyi ile sosyal medya bağımlılık puanları arasında pozitif yönde anlamlı bir ilișki olduğu görülmüș ve dürtüsellik değișkeninin toplam varyansın \%18'ni $(R=.18, p=, 00)$ açıkladığı bulunmuştur. Kadın ve erkeklerin dürtüsellik düzeylerinde ve sosyal medya bağımlııklarında anlamlı bir fark olmadığı görülmüştür.

Sonuç: Sağllk Hizmetleri Meslek Yüksekokulu öğrencilerinin oluşturduğu bu örneklemde dürtüsellik, sosyal medya bağımlılığını yordamaktadır.

Anahtar kelimeler: Sosyal medya, sosyal ağ, bağımlıık, davranışsal bağımlıık 


\section{Giriş}

Günümüzde akıllı telefonların, tabletlerin, diz üstü bilgisayarların hemen herkes tarafından kullanılabilir olması ve internetin ulaşılabilirliğinin artması, hayatımıza pek çok yönden kolaylık sağladığı gibi aynı zamanda yeni sorunları da beraberinde getirmektedir. Bu sorunlardan biri olarak karşımıza internet bağımlı̆ı̆ı ve onun bir türü olarak sosyal medya bağımlıı̆̆ı çıkmaktadır. İnternet bağımlıı̆̆ı, genel olarak kişinin internet kullanma arzusunun bastırılamaması, internet kullanımında geçirdiği süreyi giderek artırma intiyacı duyması, internet kullanımı dışında geçirdiği zamanı değersiz görmesi, internet kullanımında zaman geçiremediğinde sinirli, gergin ve huzursuz olması gibi belirtilerle ortaya çıkan ve aynı zamanda kişinin ailevi, mesleki ve sosyal hayatındaki işlevselliği olumsuz etkileyen bir durum olarak karşımıza çıkmaktadır $(1,2)$. Internet bağımlılı̆ı, günümüzde dikkat çeken bir sorun haline gelmesine rağmen henüz uluslararası tanı sınıflandırma sistemleri içerinde bir tanı olarak yer almamaktadır. Ancak Mental Bozuklukların Tanısal ve Sayımsal El Kitabının Beşinci Basımı (DSM-5) ek kısmında konu olan internet oyun bağımlı̆̆ğı ileride sınıflandırmaya girmesi planı bulunmaktadır. İnternet bağımlı̆̆ının henüz bir tanı olarak kabul edilmemesi ve net bir şekilde tanı kriterlerinin bulunmaması, bu sorunun prevelansı hakkında kesin bilgi sahibi olmamız önünde engel teşkil etmektedir. Bu konuda bilgi sahibi olabilmek için literatür çalışmalarına bakılmıştır. Cheng ve Yee lam Li tarafından yapılan ve 31 ülkeden 89.281 katılımcının dahil edildiği büyük bir metaanaliz çalışmasında internet bağımlılığının küresel yaygınlık düzeyinin \%6-6.9 olduğu belirtilmiştir (3).

Sosyal medya platformları ise, internet kullanımının yaygın bir kullanım şekli olarak dikkat çekmektedir. We Are Social ve Hootsuite tarafından hazırlanan 2021 raporuna göre, Türkiye nüfusunun \%70,8 'i sosyal medya mecralarını kullanmaktadır. Raporda ayrıca dünya genelinde sosyal medya kullanım oranının bir buçuk kat arttığı belirtilmiş olup, kullanıcılarının bir günün yaklaşık iki buçuk saatini sosyal medya mecralarında geçirdiği aktarımıştır (4). Sosyal medya bağımlılığı, normalin çok üzerinde bir süre boyunca sosyal medya kullanımı ve bu kullanım ile karakterize bir şekilde, zamanla kullanım sıkığının artması sonucunda kişinin sosyal, fiziksel ve psikolojik işlevselliğine zarar veren bir bağımlılık şekli olarak tanımlanmaktadır (5). Literatür çalışmaları patolojik internet kullanımının da tıpkı diğer bağımlııklarda olduğu gibi pek çok faktörün etkisiyle gelişebileceğini belirtmektedir. Çalısmalar yaş grubu olarak özellikle adölesanların ve genç yetişkinlerin risk altında olduğunu ortaya koymaktadır (6). Türkiye'de ve yurtdısında yapılan pek çok çalışma, üniversite öğrencilerinde internet ve sosyal medya kullanım düzeyinin oldukça yüksek olduğunu göstermektedir (7-9). Sorunlu internet kullanımı ve sosyal medya bağımlıı̆ı açısından önemli etkenler arasında yalnızlık, azalmış benlik saygısı, kişilik özellikleri gibi psikiyatrik değişkenler yer almaktadır (10). Tüm bağımlılık sorunlarında olduğu gibi internet bağımlıı̆ında en önemli değişkenlerden bir diğerinin dürtüsellik olduğu düşünülmektedir.

Dürtüsellik kavramını tartışmadan önce dürtü kavramını anlamakta yarar bulunmaktadır. Dürtü, kısaca organizmanın yaşaması için gerekli olan gerginlik durumudur diyebiliriz. Açlık, susuzluk, uykusuzluk gibi durumlar hemostazis dediğimiz organizmanın denge halini bozan uyaranlardır. Bu uyaranlar organizmada gerginliğe sebep olur ve gereksinim hali yaratırlar. Sonuç olarak bu gereksinimi gidermeye yönelik yoğun bir istek ortaya çıkmaktadır. Dürtüsellik ise, bir olayın sonuçlarını planlama ve düşünme becerilerini bozan, sabırsızlık, heyecan ve yenilik arama davranışının gelişmesine sebep olan, öz denetim eksikliği ile karakterize bir problem olarak, pek çok psikiyatrik sorunla ilişkilendirilmektedir (11). Dürtüsel davranışlar sergileyen bireyler zaman yönetimi, düşünerek hareket etme, plan yapma gibi konularda zorlanabilmektedirler (12). Dürtü kavramında açıklandığı gibi dürtüsel davranışlar daha çok haz ve doyum ilkesine göre ortaya çıkan ve dış dünyadaki mevcut koşulların ve gerçekliğin göz ardı edilmesine sebep olan davranışlardır. Dürtüselliğin alkol ve madde bağımlıı̆ı gelişimdeki rolü uzun zamandır bilinmektedir (13). Bununla birlikte dürtüsel özellikler gösteren bireylerin zamanı etkili kullanma, plan yapma, bir olayın sonucunu düşünerek hareket etme gibi konularda zorlandıkları göz önüne alındığında, sosyal medyanın patolojik kullanımında da bir etken olduğu düşünülmektedir $(12,14)$. Literatür incelendiğinde bu konuda yapıımış çalışmalar bulunmasına rağmen, henüz tanı sınıflandırma sistemi içerisinde yer almayan ancak her geçen gün önemini arttıran bir sorun olarak patolojik sosyal medya kullanımı konusunda yordayıcı 
faktörleri anlamak adına daha fazla çalışmaya intiyaç olduğu düşünülmektedir (15-18). Bu kapsamda araştırma hipotezleri şu şekildedir:

1. Öğrencilerin dürtüsellik seviyeleri ile sosyal medya bağımlııkları arasında istatistiksel olarak anlamlı bir ilişki vardır.

2. Kadın ve erkek öğrencilerin sosyal medya bağımlılı̆ı puanları arasında istatistiksel olarak anlamlı bir fark yoktur.

3. Kadın ve erkek öğrencilerin dürtüsellik düzeyleri arasında istatistiksel olarak anlamlı bir fark yoktur.

\section{Yöntem}

\section{Örneklem}

Çalışma kapsamında, nicel araştırma yönteminin bir deseni olan, "ilişkisel -korelasyon desen" kullanılmışıı. Korelasyonel araştırma şekli, iki ya da daha fazla değişken arasındaki ilişkiyi ölçmek ve bu ilişkinin derecesini belirlemek için kullanılmaktadır (19).

Çalışmanın ulaşılabilir evrenini bir devlet üniversitesinin sağlık hizmetleri meslek yüksek okulunda öğrenim gören tüm öğrenciler oluşturmaktadır (N:787). Ulaşılabilir evrenden, belli kural ya da ölçütlere göre örneklem alma işlemine örnekleme denilmektedir (20). Bu çalışmada basit (seçkisiz) örnekleme yöntemi kullanılmıştır. Örneklem sayısı belirlenirken dikkate alınan kural ölçek madde sayısı x 10 kuralı olmuştur (Sosyal Medya Bağımlıı̆ı̆ Öıçeği- Yetişkin Formu madde sayısı x 10). Bu doğrultuda araştırma kapsamında en az 200 (20 x 10) öğrenci ile çalışılması planlanmıştır. Çalışmaya dahil edilme kriteri, katıım için gönüllü olmak ve çalışma sırasında öğrenime devam etmek şeklinde belirlenmiştir. Çalışma nihai olarak bir devlet üniversitesinin sağlık hizmetleri meslek yüksek okulunda öğrenim gören 306 öğrenci ile yürütülmüştür.

\section{Işlem}

Çalışmanın etik onayı, 26.11.2020 tarihinde, Muş Alparslan Üniversitesi Bilimsel Araştırma ve Yayın Etiği Kurulu'ndan E.13795 sayıı karar ile alınmıştır. Çalışmamız kapsamında kullanacağımız ölçekler Google Forms uygulaması ile hazırlanmış olup, içinde yaşadığımız pandemi süreci nedeniyle bir devlet üniversitesinin sağlık hizmetleri meslek yüksek okulunda öğrenim gören birinci ve ikinci sınıf öğrencilerinden, online olarak toplanmıştır. Öğrencilere çalışma konusunda yüz yüze bilgi vermek ve onlardan gönüllü onam formu ile onay almak mümkün olmamıştır. Ancak öğrencilere online anketler ile birlikte bilgilendirme formu da gönderilmiş ve çalışmaya gönüllü olarak katılabilecekleri iletilmiştir. Bunun yanı sıra hazırlanan online formda ilk olarak "çalışmaya katılmayı kabul ediyor musunuz?" şeklinde bir soru oluşturulmuş ve onamları bu şekilde alınmıştır. Çalışmaya katılım gösteren öğrencilere herhangi bir ücret ya da hediye verilmemiştir. Her bir katılımcının yaklaşık 25 dakikada doldurabildiği online form, toplam 91 sorudan oluşmakta olup, katılımcıların giriş yaptıktan sonra bütün soruları aynı anda görebileceği şekilde düzenlenmiştir. Çalışma kapsamında aynı katılımcıların tekrar anket doldurmasını önlemek adına, katılımcıların anket doldurabilmesi için Google oturumu açması koşulu oluşturulmuştur. Veri kaybını önlemek adına Google Forms ayarları herhangi bir sorunun boş geçilemeyeceği şekilde düzenlenmiş ve tüm soruların yanıtlanması zorunlu kılınmıştır. Veri toplama araçları olarak Sosyodemografik Bilgi Formu, Sosyal Medya Bağımlılı̆ı Ölçeği-Yetişkin Formu ve Barratt Dürtüsellik Ölçeği Kısa Formu (BIS-11-KF) kullanıımışıtır.

\section{Veri Toplama Araçları}

\section{Sosyodemografik Veri Toplama Formu}

Araştırmacılar tarafından katılımcıların yaş, cinsiyet ve öğrenim görülen sınıf özellikleri hakkında bilgi almaya yönelik olarak hazırlanmış olan Sosyodemografik Veri Toplama Formu kullanıımıştır. Bu çalışmada araştırmak istenilen sorularla ilgisi olmadığı düşünüldüğü için "gelir durumu", "sosyoekonomik durum", "yaşanılan yer" gibi sosyodemografik özelliklere dair sorulabilecek diğer sorulara yer verilmemiştir. 


\section{Barratt Dürtüsellik Ölçeği Kısa Formu (BIS-11-KF)}

Çalışma kapsamında tercih edilen bu ölçek illk olarak Barratt tarafından 1959 yllında geliştirilmiş olup, günümüze kadar olan çalışmalarda dürtüsellik düzeyini ölçmek için kullanılan en yaygın veri toplama araçlarından biri olarak karşımıza çıkmaktadır. Geliştirildiği tarihten itibaren bu ölçek pek çok revizyona uğramıştır (21). En son yapılan revizyon çalışması sırasında Patton ve arkadaşları (1995) lisans öğrencileri, psikiyatri hastaları ve madde bağımlılığı öyküsü olan katılımcılardan oluşan toplam 824 kişiyle çalışmışlardır. Yapılan çalışma sonrası ölçek 30 maddeden ve üç faktörden oluşan bir veri toplama aracı olarak karşımıza çıkmaktadır. Ölçeğin alt faktörlerine bakıldığında plan yapmama, motor dürtüsellik ve dikkatte dürtüsellik görülmektedir. Katılımcıların maddelere, "nadiren/hiçbir zaman, bazen, sıklıkla ve hemen her zaman/her zaman" seçeneklerinden en uygun olanı işaretleyerek yanıt verdiği bu ölçek 4'lü likert tip bir araç olarak bilinmektedir. En az 30 en fazla 120 puan alınan bu ölçekte, puan arttıkça dürtüsellik düzeyinin arttığı kabul edilmektedir (12).

Ölçeğin Türkçe geçerlik ve güvenirlik çalışmaları Tamam ve arkadaşları (2008) tarafından yapıımıştır. Ölçeğin iç tutarlıı̆ını tespit etmek için Cronbach alfa değerlerine bakılmış ve bu değer toplam ölçek için 0,82, alt ölçekler için 0,64-0,80 olarak bulunmuştur. Bu değerler ölçeğin güvenirliğinin iyi olduğunu ortaya koymaktadır (.70 üstü) (22). Bu çalışmada ise ölçeğin Cronbach alfa değeri ,82 olarak bulunmuştur. Barrat Dürtüsellik Ölçeği-Kısa Formu 15 maddeden ve üç alt faktörden oluşmaktadır. Geliştirilen kısa formdan alınabilecek en düşük puan 15, en yüksek puan ise 60 olarak belirlenmiştir. Ölçekten alınan puanın artması dürtüsellik düzeyinin arttığını göstermektedir (23).

\section{Sosyal Medya Bağımlılığı Ölçeği-Yetişkin Formu (SMBÖ-YF)}

Yetişkin grupta (18-60 yaş) sosyal medya bağımlılığını ölçmeye yönelik olarak hazırlanmış bu ölçeğin geliştirilme çalışması Şahin ve Yağcı (2017) tarafından yapılmıştır. Ölçeğin güvenirliğine dair yapılan analizlerde iç tutarlılık katsayısı olan Cronbach alfa değerinin ,943 olduğu belirtilmiştir ve bu ölçeğin güvenilir olduğu ortaya konulmuştur. Sonuç olarak araştırmacılar, 18-60 yaş grubunda kullanılabilecek, 20 maddeden oluşan, beşli Likert tipi, sanal tolerans ve sanal iletişim olmak üzere iki alt boyutu bulunan bir ölçek geliştirmişlerdir (24). Bu çalışmada ise Cronbach alfa değeri ,90 olarak bulunmuştur.

\section{Veri Analizi}

Çalışma kapsamında toplanan verilerin analizi için, SPSS 22.0 programı kullanılmıştır. Katılımcıların sosyodemografik bilgilerine ilişkin frekans ve yüzde dağlımları belirlenmiştir. Bütün analizlerde gerekli varsayımlar karşılanarak parametrik testler kullanımışır. Araştırma sorusuna yönelik olarak basit doğrusal regresyon analizi yapıımıştır. Basit doğrusal regresyon analizi, bir bağımsız değişkenin, bir bağımlı değişken arasındaki ilişkiyi ve bağımsız değişkenin bağımlı değişkeni tahmin etme oranını ortaya koyabilmeyi sağlamaktadır $(22,25)$. Araştırma sorusu kapsamında, "dürtüsellik" bağımsız değişken, "sosyal medya bağımlılığı" ise bağımlı değişken olarak alınmışır. Dürtüsellik ve sosyal medya bağımlıı̆̆ı değişkenleriyle istatistiksel analiz yapmadan önce dürtüsellik ölçeği ve sosyal medya bağımlı̆̆g ölçeğinden toplanan verilerin normal dağılımına bakılmıştır. Sosyal medya bağımlıı̆ı ölçeğinin toplamı için mean:50,21; mode: 46,00; median: 49,50 değerleri bulunmuş ve bu değerler birbirine yakın olduğu için normal dağılım olduğu düşünülmüştür. Aynı zamanda basıkık ve çarpıklık değerlerinin $-3,+3$ aralığında olduğu görülmüş olup bu sonuçta normal dağııımı işaret etmektedir (26). Aynı şekilde dürtüsellik ölçeğinin normal dağııım analizi sonucu bulunan mean:26,51; mode: 23,00, median:26,00 değerleri ile dürtüsellik değişkeninde de normal dağılımın sağlandığı bulunmuştur. Ek olarak dürtüsellik ölçeği toplamına ilişkin basıklık ve çarpıklık değerlerinin -3 ve +3 aralığında olduğu görülmüştür. Basit doğrusal regresyon için yeterli örneklem, doğrusallık, anlamlı uç değerlerin olmaması, normal dağılım, eş varyanslılık varsayımlarına yönelik analizler yapılmıştır (22,25). Yeterli örneklem varsayımı için $\mathrm{N}>50+8 \mathrm{~m}$ ( $\mathrm{m}=$ bağımsız değişkenlerin sayısı) formülünden yararlanılmıştır (26). İki bağımsız değişkenimiz olan bu çalışmada en az 67 katılımcı ile çalışmamız gerekmekteydi. Çalışma örneklemimizin bu varsayımı karşıladığı görülmektedir $(\mathrm{N}=306)$. Doğrusallık varsayımını karşılamak için Pearson korelasyon katsayısına bakılmıştır. Bu çalışmada, dürtüsellik ve sosyal medya bağımlılığı arasındaki korelasyon pozitif yönde ,42 olarak bulunmuştur (Tablo 
2). Bu değerin ,3 değerinden büyük olması varsayımın karşılanması için yeterlidir (26). Araştırmada uç değerler Mahalanobis uzaklık değerleri incelenerek tespit edilmiştir (25). Uç değer görülmemiştir. Normal dağılımı değerlendirmek için P-Plot test grafiğine bakıımıştır (Şekil 1). Şekildeki noktaların düz diyagonal bir şekilde doğrusal bir dağılım gösterdiği görülmüş olup bu durum normalliği işaret etmektedir (26). Eş varyanslılık varsayımı içinse saçıım grafiği incelenmiştir. Saçlım grafiğinde verilerin kabaca dikdörtgen biçiminde dağılması beklenmektedir (26). Analiz sonucu bu varsayımın da karşılandığı görülmektedir (Şekil 2).

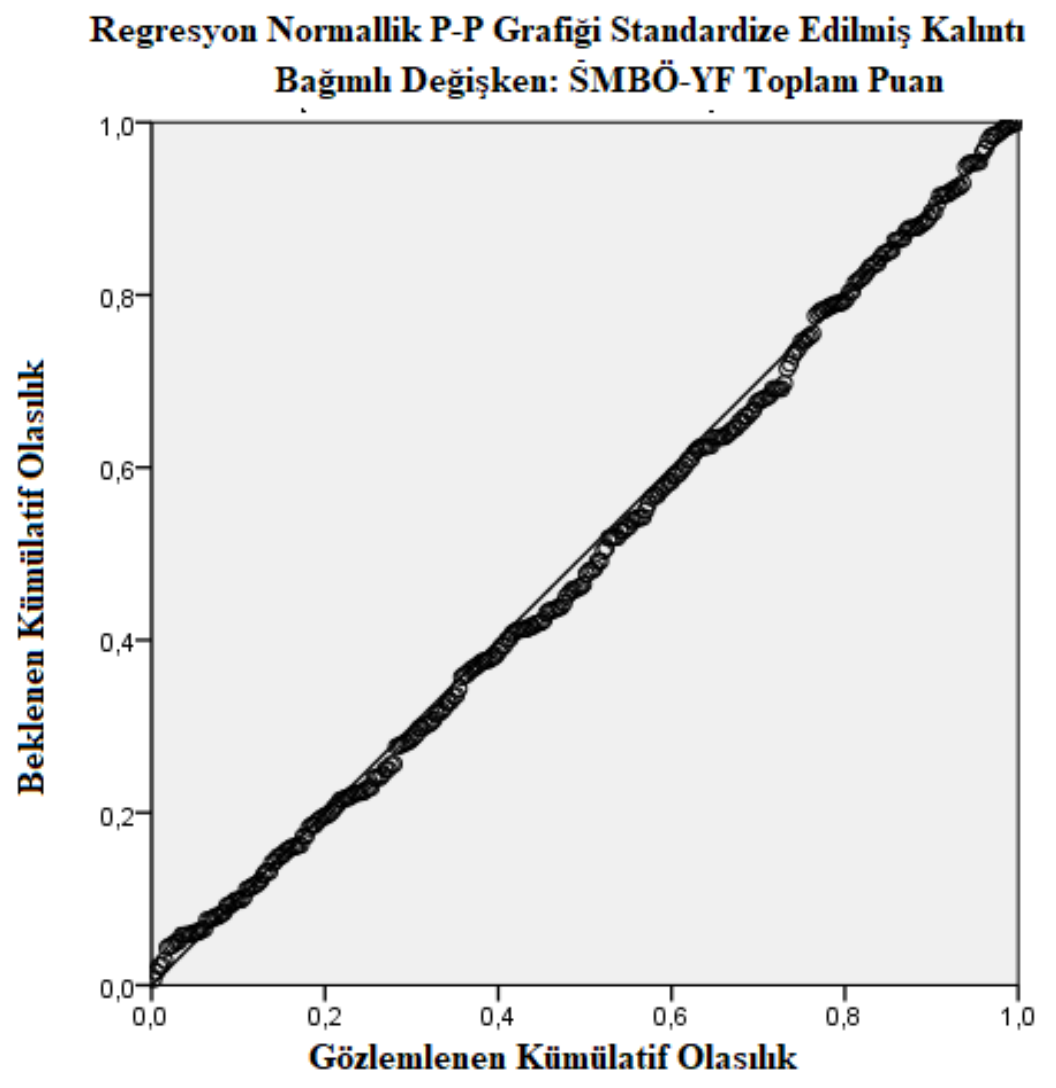

\section{Şekil 1. Normal dağılım için P-Plot test grafiği}

İlişkisiz örneklem t-testi için karşılanması gereken varsayımlar yeterli örneklem ve normal dağılım varsayımları olarak bilinmektedir (22). Normal dağılım için basıklık ve çarpıklık değerlerine bakılmıştır. Araştırmaya katııım gösteren kadın sayısı 229 ve erkek sayısı 77 olarak bulunduğu için, her bir hücrede en az 15 katılımcı olmalı kuralının karşılandığı görülmektedir (26). Normal dağıım analizi içinse çarpıklık ve basıkık değerlerine bakılmıştır (Tablo 4). Analiz sonrası Barrat Dürtüsellik Ölçeği Kısa Formu verilerinde kadın katılımcılar için basıkık değerinin ,52 çarpıklık değerinin -,43 olduğu, erkek katılımcılar içinse basıkık değerinin ,69 , çarpıklık değerinin ,66 olduğu bulunmuştur. Sosyal Medya Bağımlılık Ölçeği verilerinde basıklık değerinin kadın katılımcılar için ,20 ve çarpıkık değerinin -,31 olduğu, erkek katıımcılar içinse basıklık değeri ,53 ve çarpıklık değeri ,20 olarak bulunmuştur. Bu değerlerin "-1" ve "1" aralığında olması normal dağılımı işaret etmektedir (26). Basit doğrusal regresyon ve ilişkisiz örneklem t-testi için gerekli olan bütün varsayımlar karşılanmış olup, araştırma soru ve hipotezlerine yönelik analizlere bakılmıştır.

\section{Bulgular}

Araştırma kapsamına alınan 306 katılımcının 229'nun (\%74,8) kadın 77'sinin (\%25,2) erkek olduğu görülmektedir. Katılımcıların yaş ortalaması 20,31 1,79 olarak bulunmuştur. Çalışmaya katılan öğrencilerin 180'nin $(\% 58,8)$ birinci sınıfta 126'sının $(\% 41,2)$ ikinci sınıfta öğrenim görmektedir. 


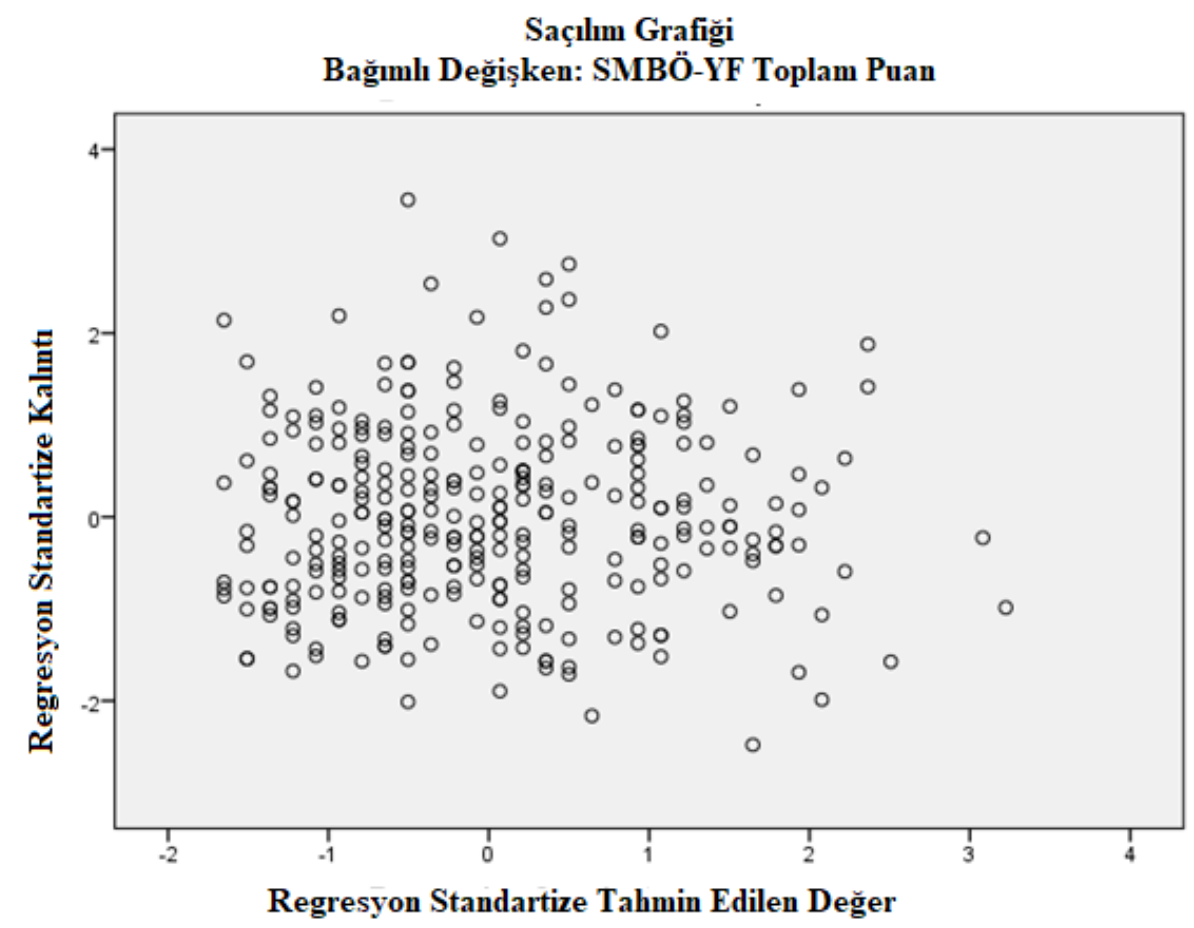

Şekil 2: Eş varyansılıık varsayımı için saçılım grafiği

Tablo 1. Katlımcıların demografik özellikleri

\begin{tabular}{|l|c|c|}
\hline Cinsiyet & $n$ & $\%$ \\
\hline Kadın & 229 & 74,8 \\
\hline Erkek & 77 & 25,2 \\
\hline SInıf & & \\
\hline 1. sınıf & 180 & 58,8 \\
\hline 2. sınıf & 126 & 41,2 \\
\hline & $X \pm$ SS & Min-Max \\
\hline Yaş & $20,31 \pm 1,79$ & $17-30$ \\
\hline
\end{tabular}

X: Ortalama, SS: Standart Sapma

Tablo 2. Değişkenlerin korelasyon düzeyi

\begin{tabular}{|l|c|c|}
\hline & SMBÖ-YF & BIS-11-KF \\
\hline SMBÖ-YF & 1,000 &, 424 \\
\hline BIS-11-KF &, 424 & 1,000 \\
\hline SMBÖ-YF & - &, $000^{*}$ \\
\hline BIS-11-KF &, $000^{*}$ & - \\
\hline
\end{tabular}

*p<0,05, SMBÖ-YF: Sosyal Medya Bağımlılığı Ölçeği- Yetişkin Formu, BIS-11-KF: Barrat Dürtüsellik Ölçeği-Kısa Formu

Sosyal medya bağımılı̆̆ı ile dürtüsellik arasındaki ilişkiye yönelik yapılan basit doğrusal regresyon analizi sonuçları Tablo 3' te verilmiștir. Tablo 3 incelendiğinde dürtüsellik düzeyi ile sosyal medya bağımlıık puanları arasında pozitif yönde anlamlı bir ilişki olduğu görülmekte olup dürtüsellik düzeyi toplam varyansın \%18' ni $(R=.18, R 2=.42, F=66.73 p=, 00)$ açıklamaktadır. Standardize edilmiş regresyon katsayısına bakıldığında ise dürtüsellik düzeyinde bir birimlik artışın sosyal medya bağımlılığı düzeyinde \%42'lik bir artışı işaret ettiği görülmektedir. Regresyon katsayısının anlamlı olmasına ilişkin t testi sonuçlarına bakıldığında ise dürtüsellik düzeyinin sosyal medya bağımlıı̆̆ı üzerinde anlamlı ve pozitif yönde bir etkisi olduğu yorumu yapılabilmektedir. 
Tablo 3. Dürtüsellik düzeyinin sosyal medya bağımlılığını yordamasına ilişkin basit regresyon analizi sonuçları

\begin{tabular}{|l|c|c|c|c|c|}
\hline Değişkenler & B & Std. Hata & B & t & , \\
\hline Sabit & 27,094 & 2,926 & & 9,259 &, 00 \\
\hline $\begin{array}{l}\text { Dürtüsellik } \\
\text { Düzeyi }\end{array}$ &, 872 &, 107 &, 424 & 8,169 &, 00 \\
\hline
\end{tabular}

$\mathrm{n}=306, \mathrm{R}=.18, \mathrm{R}^{2}=.42 \mathrm{~F}=66,73,{ }^{*} \mathrm{p}=, 00$

Tablo 4. Normal dağılım analizi tablosu

\begin{tabular}{|l|c|c|c|}
\hline & Cinsiyet & Basılklk & Çarplkllk \\
\hline BIS-11-KF & Kadın &, 52 &,- 43 \\
\hline SMBÖ-YF & Erkek &, 69 &, 66 \\
\hline & Kadın &, 20 &, 31 \\
\hline
\end{tabular}

SMBÖ-YF: Sosyal Medya Bağımlılığı Ölçeği- Yetişkin Formu, BIS-11-KF: Barrat Dürtüsellik ÖIçeği-Kısa Formu

İlişkisiz örneklem t testinde varyans homojenliğini değerlendirmek için Levene testi sonuçlarına bakılmıştır. Levene testine sonuçlarına göre anlamlılk değeri $p=.05$ 'ten büyük olduğu için Equal variance assumed değerine bakılarak $t$ testler yorumlanmıştır(26). Dürtüsellik düzeyi için yapılan test sonuçlarına bakıldığında kadınlar $(M=26.73, S S=7)$ ve erkeklerin $(M=25.87, S S=6,86$; $t(304)=, 94, p=, 34)$ puanları arasında anlamlı bir fark olmadığı görülmüştür. Sosyal medya bağımlılı̆ı için yapılan t test sonuçlarında ise kadınların puanları $(M=49.91, S S=14)$ ile erkelerin puanları $(M=51.11, S S=15,32$; $t(304)=-, 63, p=52)$ arasında da anlamlı bir fark olmadığı bulunmuştur (Tablo 5).

Tablo 5. Cinsiyete göre dürtüsellik ve sosyal medya bağımlılı̆ı düzeylerine ilişkin bulgular

\begin{tabular}{|c|c|c|c|c|c|c|c|}
\hline & Cinsiyet & $\mathrm{N}$ & $X$ & SS & $\mathrm{Sd}$ & $t$ & $p$ \\
\hline \multirow[t]{2}{*}{ BIS-11-KF } & Kadın & 229 & 26,73 & 7,00 & 304 & ,940 & ,348 \\
\hline & Erkek & 77 & 25,87 & 6,86 & & & \\
\hline \multirow[t]{2}{*}{ SMBÖ-YF } & Kadın & 229 & 49,91 & 14,00 & 304 & -,637 & ,524 \\
\hline & Erkek & 77 & 51,11 & 15,32 & & & \\
\hline
\end{tabular}

SMBÖ-YF: Sosyal Medya Bağımlılığı Ölçeği- Yetişkin Formu, BIS-11-KF: Barrat Dürtüsellik Ölçeği-Kısa Formu

\section{Tartışma}

Yapılan çalışmada sağlık bilimleri meslek yüksekokulu öğrencilerinin dürtüsellik düzeylerinin sosyal medya bağımlılığını yordama derecesi incelenmiş ve kadın ve erkek öğrencilerin dürtüsellik düzeyleri ile sosyal medya bağımlılığı düzeyleri arasında anlamlı bir fark olup olmadığı değerlendirilmiştir. Araştırma sonucunda dürtüsellik değişkeninin sosyal medya bağımlılığını \%18 oranında anlamlı bir şekilde açıkladığı bulunmuştur. Bu sonuca göre dürtüsellik düzeyinin sosyal medya bağımlılığında bir yordayıcı olduğu yorumu yapılabilmektedir.

Literatürde yer alan pek çok çalışma, araştırma sonucunda ulaşılan verileri desteklemektedir. Savcı ve Aysan (2016) tarafından yapılan çalışmada, 307 üniversite öğrencisi ile çalışılmış ve dürtüselliğin önemli ve doğrudan bir etkiyle sosyal medyanın patolojik kullanımına sebep olduğu sonucuna ulaşılmıștır (16). Ünsalver ve Aktepe (2017) tarafından üniversite öğrencileri ile yapılan başka bir çalışmada dürtüsellik ile internet bağımlılığı arasında güçlü bir ilişki olduğu belirtilmiş ve öğrencilerin daha çok sosyal medya mecralarını kullanmak için internete eriştiği eklenmiştir (17). Cudo ve arkadaşları (2020) tarafından, Facebook bağımlılı̆ı ile öz denetim ve dürtüselliğin ilişkisinin incelendiği bir çalışmada ise dürtüsel özelliklerin öz denetimi zayıflattığı ve Facebook bağımlıı̆ıının bir yordacısı olduğu sonucuna ulaşıımıştır (18). Cao ve arkadaşları tarafından (2007) yapılan çalışmada 2620 lise öğrencisi ele alınmış ve çalışma sonucunda internet bağımlılığı olan adolesanların, olmayanlara göre daha yüksek dürtüsellik puanına sahip oldukları vurgulanmıştır (15). 
Çalışma kapsamında ulaşılan sonuçlara göre kadınlarda dürtüsellik ölçeği puanlarının erkeklerden yüksek olduğu görülmekle birlikte sonucun istatistiksel olarak anlamlı olmadığı bulunmuştur. Literatür incelendiğinde cinsiyet değişkenine göre dürtüselliği ele alan çalışmaların farklı sonuçlara ulaştığı görülmüştür. Alan yazında iki cinsiyetin dürtüsellik puanları arasında fark olmadığına ilişkin çok sayıda çalışma görülmüştür $(27,28,29)$. Aynı zamanda iki cinsiyet arasındaki farka işaret eden çalişmalar da mevcuttur $(30,31)$. Silverman (2003) tarafından yapılan çalışmada kadın katılımcılarının hazzı erteleme becerilerinin erkeklere oranla daha yüksek olduğu belirtilmiştir (32). Dittrich ve Leipold (2014), erkeklerde daha büyük ve geç bir ödül yerine anlık ve daha küçük bir ödülün tercih edilme düzeyinin kadınlara oranla daha yüksek olduğunu bildirmiştir (33). Ancak bu konuda da çelişkiye işaret eden literatür çalışmaları bulunmaktadır (34). Bu durum menstrual döngü sırasında ortaya çıkan hormonal değişimlerin sinir sistemini etkilemesi ile açıklanabilmektedir (35).

Bu çalışma sonucunda erkeklerin sosyal medya bağımlılık ölçeğinden aldığı puanların kadınların aldığı puanlardan yüksek olduğu görülmekle birlikte puanlar arasındaki fark istatistiksel olarak anlamlı bulunmamıştır. Literatürde bu bulguya paralel çalışmalar yer almaktadır $(36,37)$. Alan yazın incelendiğinde kadın ve erkek sosyal medya kullanıcılarının, uygulamayı kullanma amaçlarının farkılığını işaret eden çalışmalar dikkat çekmiştir. Mazman ve Koçak Usluel tarafından (2011) Facebook kullanıcıları ile yapılan çalışmada kadınların uygulamayı daha çok gelişmeleri takip etmek amacıyla erkeklerin ise iletişim kurmak amacıyla kullandıkları, kadınların eski arkadaşlarla iletişim kurmayı, erkeklerin ise yeni arkadaşlar bulmayı tercih ettikleri belirtilmişsir (38). Rousseau ve Puttaraju (2014) tarafından yapılan çalışmada da erkek kullanıcıların kadınlara oranla daha fazla etkileşim kurmak ve yeni arkadaşlar edinmek için sosyal medya uygulamaları kullandıklarına dikkat çekilmiştir (39).

Bu çalışmada Barrat Dürtüsellik Ölçeği' nin "dikkatte dürtüsellik", "motor dürtüsellik" ve "plan yapmama" şeklindeki alt faktörleri ile sosyal medya bağımlılı̆ı arasındaki ilişki ayrı ayrı incelenmemiştir. Bunun sebebi alt faktörlerin sosyal medya bağımlıı̆ını yordama derecesine ve yordama açısından aralarında fark olup olmadığına yönelik bir hipotez oluşturulmamasıdır. Bu durum çalışma açısından bir kısıtlılık olarak değerlendirilebilir. Aynı zamanda bu çalışma bir devlet üniversitesinin sağlık hizmetleri meslek yüksek okulunda, 2020-2021 güz döneminde öğrenim gören öğrenciler ile sınırıdır. Tüm bunlara ek olarak bu çalışma incelenen değişkenler, kullanılan ölçme araçları ile elde edilen verilerle sınırlıdır.

Sonuç olarak bu çalışmada henüz tanı sınıflandırma sistemi içerisinde yer almayan sosyal medya bağımlılığında, olası bir etiyolojik faktör olan dürtüsellik değişkeninin yordayıcı olduğu bulunmuştur. Aynı zamanda kadın ve erkekler arasında dürtüsellik ve sosyal medya bağımllığı açısından anlamlı bir fark olmadığı ortaya konulmuştur. Türkiye'nin farklı bölgelerinde daha geniş örneklemle yapılabilecek nicel çalışmaların, dürtüsellik ve sosyal medya bağımlılı̆ı arasındaki ilişkiyi evrene genelleyebilmek adına yararlı olabileceği düşünülmektedir. Aynı zamanda yapılacak çalışmalarla dürtüsellik alt faktörleri ile sosyal medya bağımlılığı arasındaki ilişkinin ve alt faktörlerin sosyal medya bağımlılı̆ını yordama açısından birbirinden farklı olup olmadığının incelenmesinin de yararlı olabileceği düşünülmektedir.

\section{Kaynaklar}

1. Young KS. Internet addiction. Am Behav Sci 2004; 48(4): 402-441.

2. Dalbudak E, Evren C, Aldemir S, et al. Relationship of Internet addiction severity with depression, anxiety, and alexithymia, temperament and character in university students. Cyberpsychol Behav Soc Netw 2013; 16(4): 272-278.

3. Cheng C, lam Li Y. Internet addiction prevalence and quality of (real) life: A meta-analysis of 31 nations across seven world regions. Cyberpsychol Behav Soc Netw 2014; 17(12): 755-760.

4. We Are Social. Digıtal 2021. https://wearesocial.com/digital-2021 (1 Haziran 2021' de ulaşıldı).

5. Illiş A, Gülbahçe A. Sosyal medya bağımlılı̆ı ile iletişim becerileri arasındaki yordayıcı ilişsinin incelenmesi. Ekev Akademi Derg 2019; 23(78): 45-60.

6. Kawabe $\mathrm{K}$, Horiuchi $\mathrm{F}$, Ochi $\mathrm{M}$, et al. Internet addiction: Prevalence and relation with mental states in adolescents. Psychiatry Clin Neurosci 2019; 70(9): 405-412. 


\section{Bağımlılık Dergisi - Journal of Dependence}

7. Goel D, Subramanyam A, Kamath R. A study on the prevalence of internet addiction and its association with psychopathology in Indian adolescents. Indian J Psychiatry 2013; 55(2): 140-143.

8. Ehrenberg A, Juckes S, White KM, Walsh SP. Personality and selfesteem as predictors of young people's technology use. Cyberpsychol Behav 2008; 11(6): 739-774.

9. Berigel M, Kokoc M, Karal H. Exploring pre-service teachers' level of social networking sites addictive tendencies. Eurasian Journal of Educational Research 2012; 12 (49A): 215-228.

10. Yen JU, Chih-Hung K, Cheng-Fang Y, et al. Psychiatric symptoms in adolescents with internet substance use. Psychiatry Clin Neurosci 2008; 62(1): 9-12.

11. Carver CS. Impulse and constraint: Perspectives from personality psychology convergence with theory in other areas, and potential for integration. Pers Soc Psychol Rev 2005; 9(4): 312-333.

12. Patton JH, Stanford MS, Barratt ES. Factor structure of the Barratt Impulsiveness Scale. J Clin Psychol 1995; 51(6): 768-774.

13. Brand $M$, Young KS, Laier $C$. Prefrontal control and internet addiction: A theoreticarl model and review of neuropsychological and neuroimaging findings. Front Hum Neurosci 2014; 8: 1-13.

14. Kuss DR, Griffiths MD. Online social networking and addiction: A review of the psychological literature. Int $J$ Environ Res Public Health 2011; 8(9): 3528-3552.

15. Cao F, Su L, Liu T, Gao X. The relationship between impulsivity and internet addiction in a sample of Chinese adolescents. Eur Psychiatry 2007; 22(7): 466-471.

16. Savcı M, Aysan F. Relationship between Impulsivity, Social media usage and loneliness. Educational Process: International Journal 2016; 5(2): 106-115.

17. Ünsalver BA, Aktepe H. Internet addiction and impulsivity among university students. Eur Psychiatry 2017; 41 (S1): S397.

18. Cudo A, Torój M, Demczuk M, Francuz P. Dysfunction of self-control in Facebook addiction: Impulsivity is the key. Psychiatr Q 2020; 91: 91-101.

19. Kalaycı Ş. SPSS Uygulamalı Çok Değişkenli İstatistik Teknikleri. 3. Baskı, İstanbul: Asil yayınclık, 2008: 217235.

20. Ekiz D. Bilimsel Araştırma Yöntemleri. 6.Baskı, Ankara: Anı Yayıncılık, 2020: 112-118.

21. Stanford MS, Mathias CW, Dougherty DM, et al. Fifty years of the Barratt Impulsiveness. Pers Individ Dif 2009; 47(5): 385-395.

22. Pallant J. SPSS Kullanma Klavuzu, Balcı S ve Ahi B (Çevirenler). 3.Baskı, Ankara: Anı Yayınclık, 2020: 113118.

23. Tamam L, Güleç H, Karataş G. Barratt Dürtüsellik Ölçeği Kısa Formu (BIS-11-KF) Türkçe Uyarlama Çalısması. Nöropsikiyatri Arşivi Dergisi 2013; 50: 130-134.

24. Şahin C, Yağcı M. Sosyal Medya Bağımlılı̆ı Ölçeği- Yetişkin Formu. Ahi Evran Üniversitesi Kırşehir Eğitim Fakültesi Dergisi 2017; 18 (1): 523-538.

25. Büyüköztürk Ş.Sosyal Bilimler İçin Veri Analizi El Kitabı: İstatistik, Araştırma Deseni Spss Uygulamaları ve Yorum. 28.Baskı, Ankara: Pegem Akademi, 2020: 93-119.

26. Pallant J. SPSS Kullanma Klavuzu, Balcı S ve Ahi B (Çevirenler).3.Baskı, Ankara: Anı Yayıncılık. 2020: 164-198.

27. Feingold A. Gender differences in personality: A meta-analysis. Psychol Bull 1994; 116(3): 429-456.

28. Patton JH, Stanford MS, Barratt ES. Factor structure of the Barratt Impulsiveness Scale. J Clin Psychol 1995; 51(6): 768- 774.

29. Reynolds B, Ortengren A, Richards JB, De Wit H. Dimensions of impulsive behavior: personality and behavioral measures. Pers Individ Dif 2006; 40(2): 305- 315.

30. Marazziti D, Baroni S, Masala I, et al. Impulsivity, gender, and the platelet serotonin transporter in healthy subjects. Neuropsychiatr Dis Treat 2010; 6(1): 9-15.

31. Stoltenberg SF, Batien BD, Birgenheir DG. Does gender moderate associations among impulsivity and healthrisk behaviors?. Addict Behav 2008; 33(2): 252-265.

32. Silverman I. Gender differences in delay of gratification: A meta-analysis. Sex Roles 2003; 49: 451-463.

33. Dittrich M, Leipold K. Gender differences in time preferences. Econ Lett 2014; 122: 413-415.

34. Beck RC, Triplett MF. Test-retest reliability of a group-administered paper-pencil measure of delay discounting. Exp Clin Psychopharmacol 2009; 17(5): 345-355.

35. Hosseini-Kamkar N, Morton JB. Sex differences in self-regulation: An evolutionary perspective. Front Neurosci 2014; 8: 1-8.

36. Çömlekçi MF, Başol 0. Gençlerin sosyal medya kullanım amaçları ile sosyal medya bağımlılığı ilişkisinin incelenmesi. Celal Bayar Üniversitesi Sosyal Bilimler Dergisi 2019; 17(4): 173-188. 


\section{Bağımlılık Dergisi - Journal of Dependence}

37. Aktan E. Üniversite öğrencilerinin sosyal medya bağımlılık düzeylerinin çeşitli değişkenlere göre incelenmesi. Erciyes Illetişim Dergisi 2018; 5(4): 405-421.

38. Mazman SG, Koçak Usluel Y. Gender differences in using social networks. The Turkish Online Journal of Educational Technology 2011; 10(2): 133-139.

Rousseau SJM, Puttaraju K. A study on gender differential factors in uses of social networking sites. International Journal of Humanities and Social Science Invention 2014; 3(11): 31-40. 